\title{
IMPORTANCE OF CORPORATE SOCIAL RESPONSIBILITY IN BRAND VALUE OF FRUITS AND VEGETABLES
}

\author{
Antonio Marín Armero
}

Universidad Politécnica de Valencia, Spain

\begin{abstract}
Brand equity on products such fruits and vegetables is a topic that has not yet been extensively studied as they are often perceived by consumers as a low value added and thus very sensitive to price competition. A revision of this value proposition is very relevant nowadays as there are more fruits and vegetables new brands that are coming and entering the market. The aim of this study is to validate the brand equity scale for fruits and vegetables and to configure whether any of the brand value dimensions are the factors for a consumer to pay for a premium price. The background of this study is backed by quantitative survey of fresh produce consumers in Spain. The survey shows that Corporate Social Responsibility (CSR) is one of the significant determinants of a consumer to pay for a premium price for a specific fruit. We can conclude that consumer's gives more emphasis to a brand that has strong Corporate Social Responsibility (CSR) additionally this may have strong implications in brand management and corporate benefits in fruit and vegetables companies.
\end{abstract}

Keywords: brand value; fruit; CSR; premium price

\section{Introduction \& Framework}

Branding has been around for centuries as a mean to distinguish the goods of one producer from another, and nowadays it is regarded as one of the most important assets for companies (Keller, 2013). However, branding has not been really present in fresh produce such as fruit and vegetables (Rickart, 2013, et al). Over the past decades several authors have developed various proposals to establish models to measure Brand Value from the consumer perspective (Aaker, 1991, Keller, 1993). In recent years, numerous authors have used the said models to measure brand value from the perspective of the consumer for all types of products and sectors (Samsita, 2015) including food products (Kathuria, 2013). Other authors have chosen to transfer these models to a specific country such as Spain (Buil, 2013). However, there are few studies that have focused exclusively on brand value in fresh products such as fruits and vegetables, and also, these studies are not recent (Beverland, 2001, Nijssen, 1998).

Brand equity is a set of brand assets and liabilities linked to a brand name and symbol, which add to or subtract from the value provided by a product or service. Brand equity model has four dimensions, these dimensions are (Aaker, 1991):

Brand Awareness

Perceived Quality

Brand Loyalty

Brand Associations 
Brand Associations is anything that links the consumer's mind to the brand (Aaker, 1991). It can also be measured with many different items depending on the industry, such as Uniqueness, Perceived Added Value and Corporate Social Responsibility (Anselmssom, 2014).

In this study, we aim:

To validate a scale in four dimension to measure Brand Equity in fruits and vegetables.

To configure whether the Corporate Social Responsibility as a part of a Brand Value dimension, is a factor for a consumer to pay for a premium price.

\section{Materials and Methods}

\section{Data collection:}

Brands from three different fruit and vegetables categories, kiwi, tomato and banana, were chosen for the present study. The brand equity, brand dimensions and price premium were all captured empirically through a quantitative survey. Pre-test was made to select brands that have more than 50\% of awareness in Spanish market. Primary data were gathered using pretested and structured questionnaires including socio-demographic characteristics and consumer behavior. 383 Spanish consumers/buyers of fresh fruit and vegetables responded the online questionnaire in 2017. Participants were obtained through a networking procedure often referred to as snowball sampling (Magnier, 2016). A total of 55\% of the respondents were women and $45 \%$ men.

\section{Measurement:}

A five-point Likert-scale questionnaire was sent to respondents in which they describe their perceptions of three different brands. The construction of the questionnaire and its items follows previous scales, models and recommendations, primarily within the field of brand equity found in the relevant literature (Aaker, 1996, Anselmsson et al, 2014, Buil et al, 2013, Yoo and Donthu 2001, Netemeyer et al, 2004).

Multiple regression analysis and factor analysis were performed using R-Commander software package to configure whether any of the brand value dimensions are the factors for a consumer to pay for a premium price. Within the Brand Association dimension, Corporate Social Responsibility item was highlighted and studied.

\section{Results.}

\section{Results: Scale}

A scale for Brand equity was proposed and tested with three different brands associated with the following brand dimensions:

Brand Awareness

Perceived Quality

Brand Loyalty

Brand Associations:

Uniqueness.

Perceived Added Value. 
Corporate Social Responsibility (CSR)

Cronbach's Alpha values were based on standardised items computed for the scales in each of the categories. The Alpha values result was ranged from 0.95 to 0.96 -- indicating that the scales developed in this study were acceptable and reliable (Hair et al., 1998).

\section{Results: Demographics}

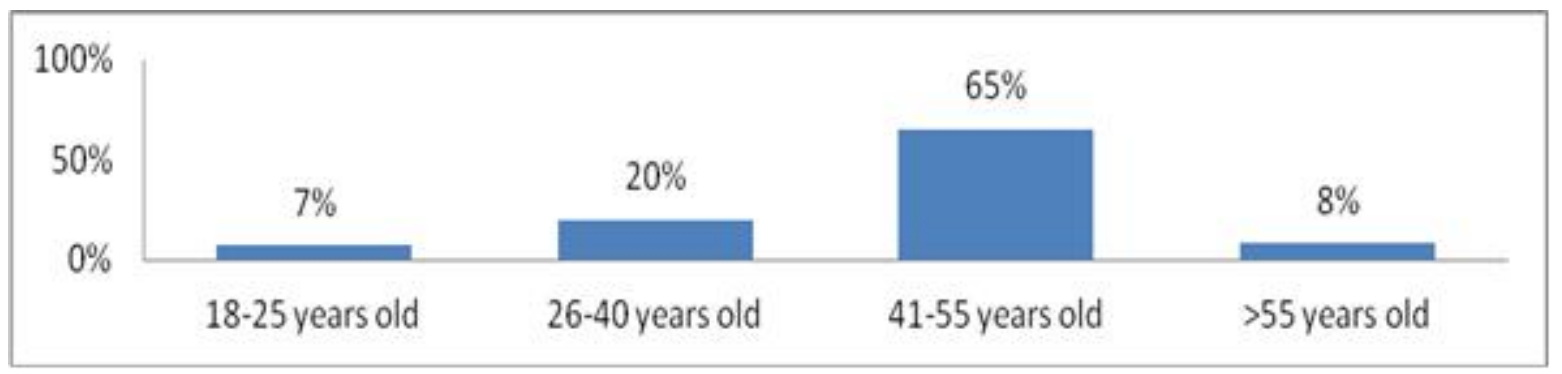

Figure 1 Age groups of respondents.

Shown in Figure 1 are the age groups of buyers/consumer that responded the online survey, most of them are between 41-55 years old.

\section{Results: Consumer Behavior.}

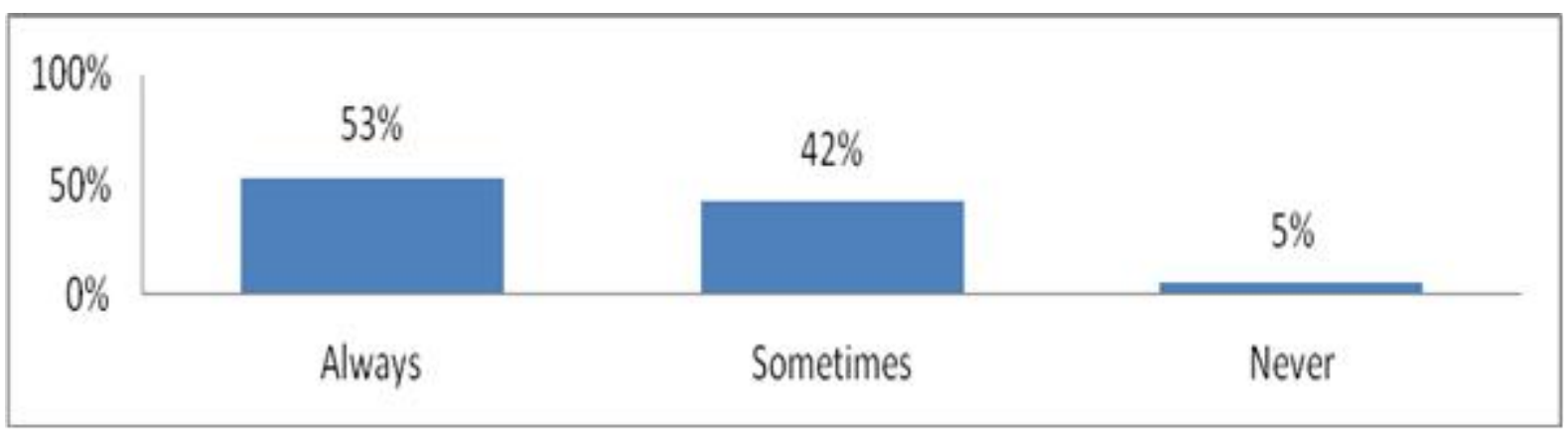

Figure 2 Percentage of respondents that are in charge of buying fresh fruits and vegetables at home.

In Figure 2 we can see the response to the question: "Are you in charge of buying fresh fruits and vegetables at home?" Figure shows that most respondents are always in charge and only $5 \%$ are never in charge of buying fresh produce at home.

Results: Brands.

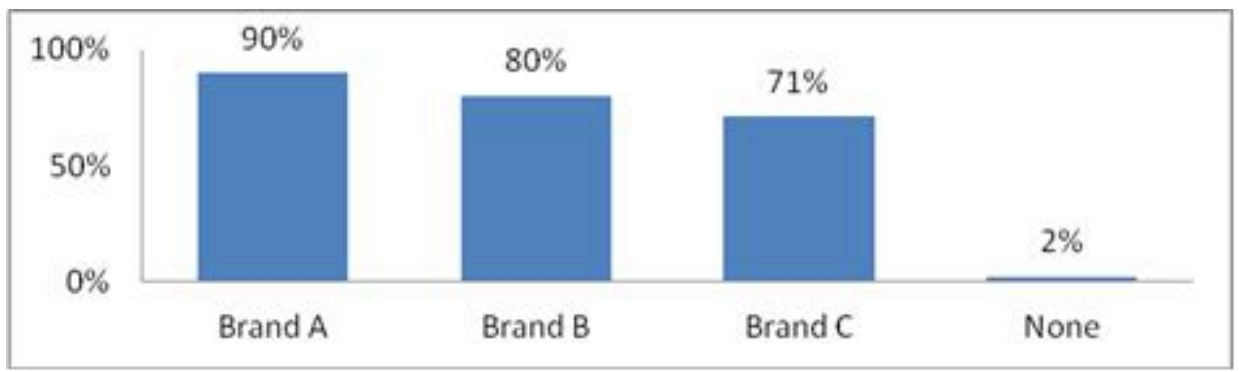

Figure 3 Brand awareness percentage for brands studied. 
Shown in Figure 3 the brand awareness percentage of the three categories of fruits and vegetables studied that is more than $50 \%$ in every brand selected as previously stated.

\section{Results: Multiple Regressions.}

Multiple regression analysis was performed to configure whether any of the brand value dimensions are the factors for a consumer to pay for a premium price.

Within the Brand Association dimension, CSR item was highlighted and studied.

Table 1 Multiple regression for Brand A

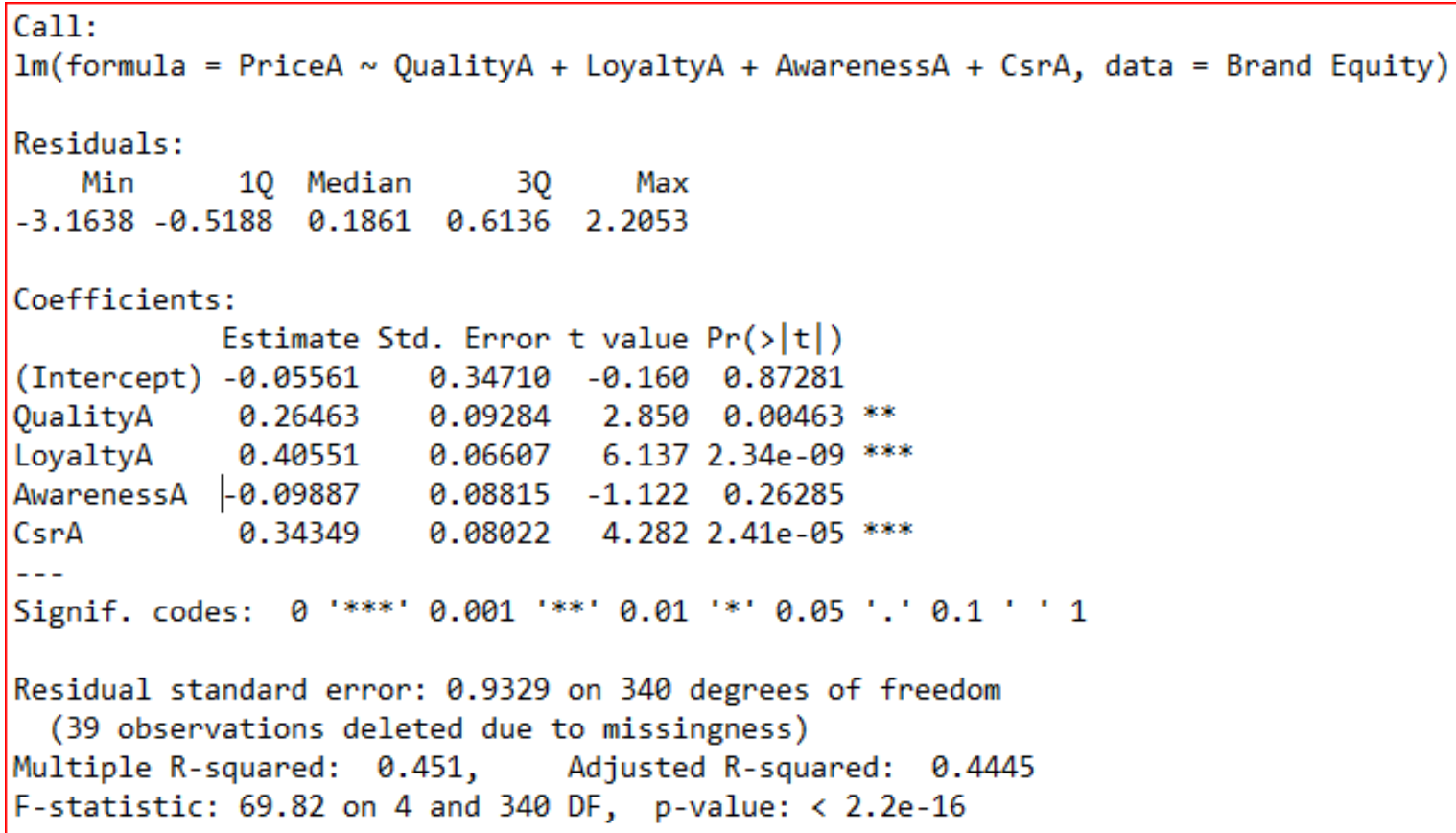

Table 1 shows that there is a significant and positive direction relationship between Corporate Social Responsibility and willingness to pay a price premium on the Brand A. 
Table 2 Multiple regression for Brand B

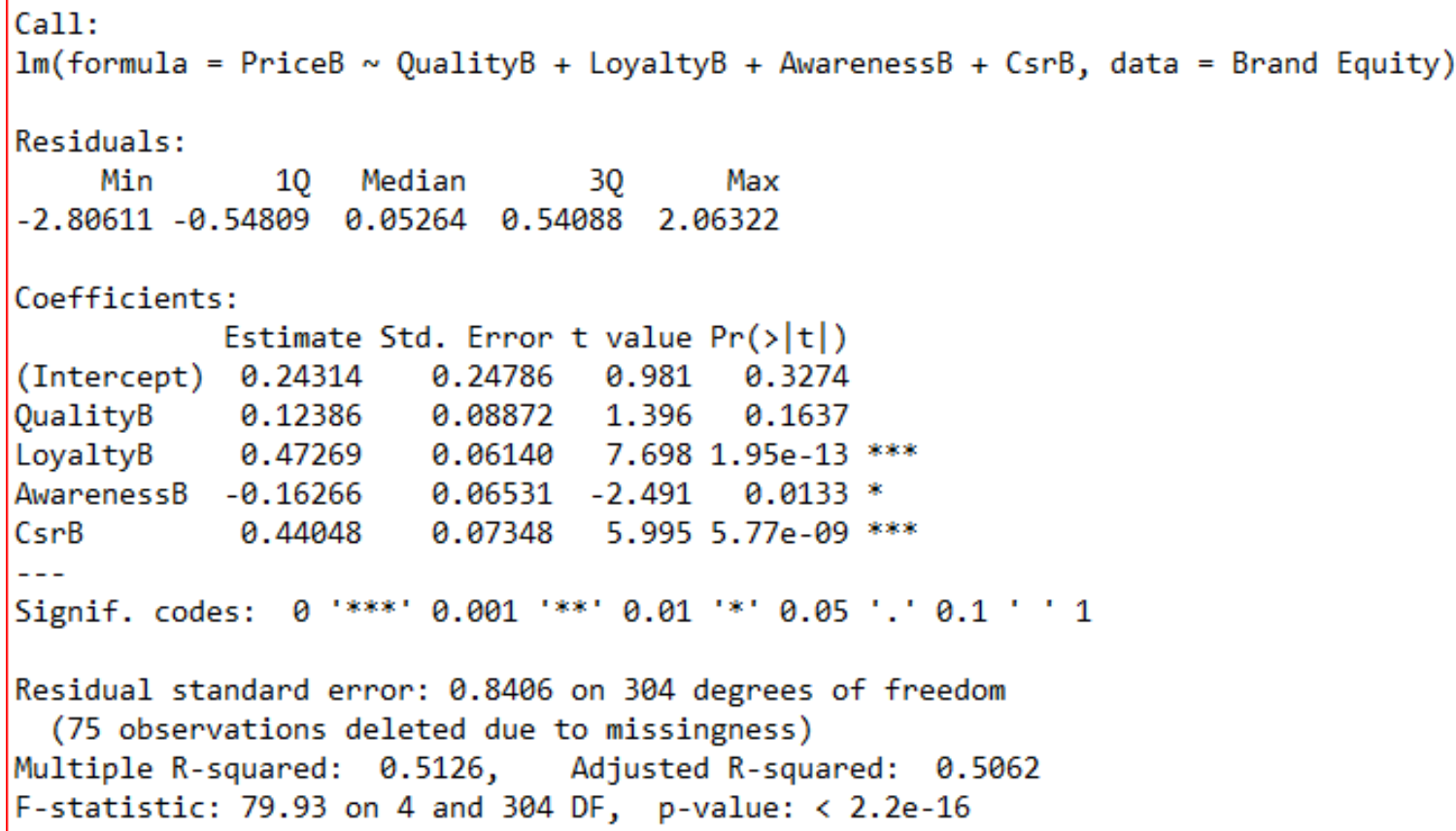

Table 2 shows that there is a significant and positive direction relationship between Corporate Social Responsibility and willingness to pay a price premium on the Brand B.

Table 3 Multiple regression for Brand C

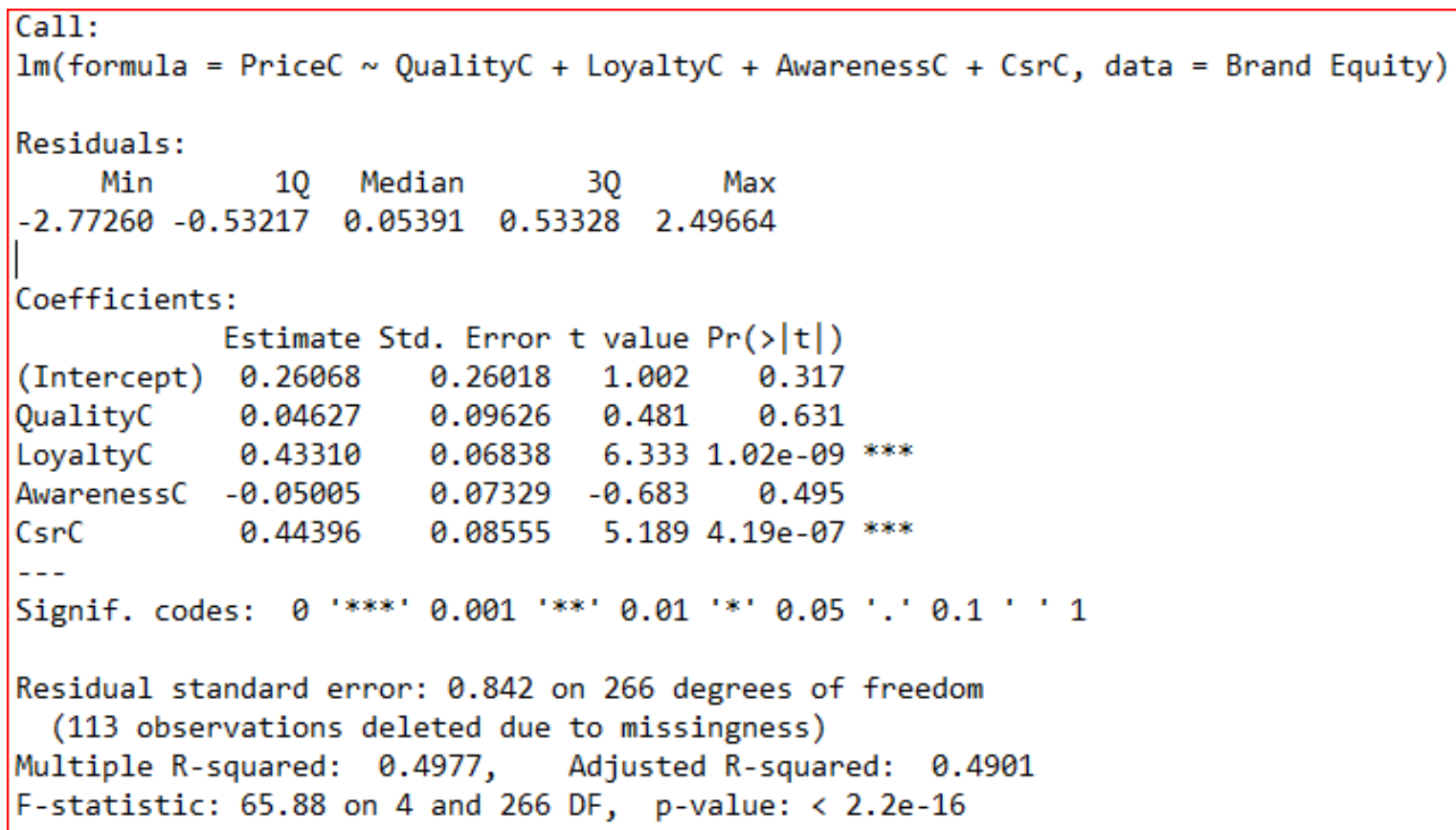

Table 3 shows that there is a significant and positive direction relationship between Corporate Social Responsibility and willingness to pay a price premium on the Brand C. 
The bivariate correlations based on Pearson, shows that all variables have a significant positive correlation. An analysis of collinearity is thus needed. The collinearity diagnostics of VIF $>5(1,66$ to 3,34$)$ shows no problem of multicollinearity (Kutner, 2004).

Tables 1, 2 and 3 show that there is a significant and positive direction relationship between CSR and price premium with $\mathrm{p}<0,001$ on the three brands that are being studied. Beta coefficients show that the consumers that give a point higher in the five-point Likert-scale RSC item, give 0,34 to 0,44 points more average in the premium price item, all other factors remaining equal. This means that Corporate Social Responsibility (CSR) is a strong predictor of customers' willingness to pay a price premium in all three studied brands

Tables 1, 2 and 3 show that brand dimensions like quality or awareness are not always statistically significant for every brand studied when considered as a factor to pay a price premium.

The models have and adjusted R-square of 0,44 to 0,51 and are statistically significant with a p-value $<2,2 \mathrm{e}-16$.

\section{Conclusions}

We can conclude that measuring Brand Equity from a consumer perspective can be done in fresh fruit and vegetables brands based on the brand dimensions proposed.

We can also conclude that consumers gives more emphasis to a specific fresh fruit or vegetable brand that has strong Corporate Social Responsibility (CSR).

\section{Implications}

This study shows a valid and reliable scale for measuring brand equity in the fresh fruit and vegetables industry, companies can develop benchmarking tools by using this measure. They can observe brand performance from a consumer perspective and track the changes over time.

Corporate Social Responsibility is a stronger predictor of consumer's willingness to pay a premium price in the fresh fruit and vegetable industry than other brand dimensions such as quality or awareness.

Focus on CSR when building a brand may be a factor that can differentiate from competitors in a profitable way

\section{Limitations}

This study is limited to the top brand in each of the three fruit and vegetable categories that have been studied. There are possibilities for future research in different categories or in different brands within the same category.

Establishing the relationships between the model's brand equity dimensions and business performance indicators, such as market share, profitability, return on investment, will be a challenging but worthwhile effort for future research.

\section{References}

Aaker, D.A., 1996, Measuring brand equity across products and markets, California Management Review, 38 (3), 102-120.

Aaker, D., 1991, Managing Brand Equity. Capitalizing on the Value of Brand Name (New York, USA: The Free Press)

Anselmsson, J., Vestman Bondesson, N., Ulf Johansson, U., 2014, Brand image and customers' willingness to pay a price premium for food brands, Journal of Product \& Brand Management, 23 (2), 90 - 102 
Beverland M., 2001, Creating value through brands: the ZESPRI ${ }^{\mathrm{TM}}$ kiwi fruit case. British Food Journal, 103 (6), $383-399$

Buil I, De Chernatony L, Martínez E. 2013 La importancia de medir el valor de marca desde la perspectiva del consumidor: Evidencia empírica en España y el Reino Unido. Revista de Ciencias Sociales, 19 (2), 226 - 237

Hair, J.R., Anderson, R.E., Tatham, R.L. and Black, W.C. 1998, Multivariate Data Analysis, (Englewood Cliffs, NJ, USA: Prentice-Hall International)

Kathuria L.M., Gill P . 2013 Purchase of branded commodity food products: empirical evidence from India. British Food Journal, 115 (9), 1255 - 1280

Keller KL. 1993 ,Conceptualizing, Measuring, and Managing Customer- Based Brand Equity. Journal of Marketing. 57, 1-22.

Keller, K. L., 2013, Strategic Brand Management: Building, Measuring and Managing Brand Equity (Harlow, U.K.: Prentice Hall)

Kutner, M. H., Nachtsheim, C. J., Neter, J., 2004, Applied Linear Regression Models (Irwin, USA: McGraw-Hill) Magnier, L., Schoormans, J., Mugge, R., 2016, Judging a product by its cover: Packaging sustainability and perceptions of quality in food products, Food Quality and Preference, 53, 132-142

Masuda K., Kushiro S., 2018, Influence of brand equity on the price premium for private labels in fresh produce: A contingent valuation survey. Agribusiness, 34, 338-350.

Netemeyer, R.G., Krishnan, B., Pullig, C., Wang, G., Yagci, M., Dean, D., Ricks, J. and Wirth, F., 2004, Developing and validating measures of facets of customer-based brand equity, Journal of Business Research, 57 (2), 209-224

Nijssen E.J., van Trip H.M.C., 1998 Branding Fresh Food Products: Exploratory Empirical Evidence from the Netherlands. European Review of Agricultural Economics, 25(2), 228-242

Rickart, B. J., Schmit, T. M., Gomez, M. I. , Lu H., 2013, Developing brands for patented fruit varieties: Does the name matter? Agribusiness, 29 (3), 259-272.

Sasmita J, Suki N.M., 2015 Young consumers' insights on brand equity. International Journal of Retail \& Distribution Management, 43 (3), 276 - 292

Yoo, B. and Donthu, N. (2001), Developing and validating multidimensional consumer-based brand equity scale, Journal of Business Research, 52 (1), 1-14. 